\title{
Assessment of effects of property taxes imposed on small and medium enterprises in Irkutsk oblast
}

\author{
Galyautdinov Ildus Ilyasovich \\ Institute of Economics, Management and Law, \\ Irkutsk National Research Technical University \\ Irkutsk, Russia \\ iliga@irk.ru
}

\begin{abstract}
The article describes the results of the three-year research on possible economic and social effects of the changes in the Act of Irkutsk oblast "On the property tax" on small and medium businesses of Irkutsk, Angarsk, Bodaybo, UsolyeSibirskoe, Sayansk, Tulun and Shelekhov. The article shows the dependence of property tax rates and the number of small enterprises which will be forced to go out of business or to go into a shadow economy. It was found that the maximum property tax rate of $2 \%$ proposed by the Government of Irkutsk oblast will have negative effects on the regional economy, increase the number of the unemployed, decrease investment attractiveness and yield a reverse effect. Tax revenues of the regional budget will decrease rather than increase. If the tax rate is $0,2 \%$, tax effects will be less destructive, but can also have negative impacts. Negative effects of the property tax depend on the floor area of properties. If the size is more than $5000 \mathrm{~m}^{2}$, there will be no negative effects. It is shown that initiators of the regional law disregard existing tax and quasi-tax pressure on enterprises which puts the brakes on their development.
\end{abstract}

Keywords - taxes, property, small enterprises, business activity.

\section{INTRODUCTION}

In 2015, the author published the results of my research on possible economic and social effects of the changes in the Act of Irkutsk oblast on "On the property tax" on small and medium enterprises (SMEs) [1]. That article justified a thesis statement about the fatality of the tax rate of 2 percent of the cadastral property value for most SMEs owning facilities with a floor area of less than $1000 \mathrm{~m}^{2}$.

This issue was being discussed by the general public involving regional lawmakers, government agents, representatives of noncommercial associations of businesses. It was being discussed by participants of scientific conferences held by Irkutsk National Research Technical University. In November 2015, the debate was broadcasted live. As a result of violent disputes, the law of Irkutsk oblast was adopted in its first reading without increasing the tax rate which is still at issue.

Public disputes are good news as they bear witness of developing inclusive economic institutes in Russia. According to some fundamental researches, inclusive economic institutes (as distinct from extractive ones) contribute to the economic growth, increase labor productivity and prosperity [16]. "Protected private property rights are a key element of the inclusive institutes because only those enterprises whose property rights are protected will perform investment activities and increase labor productivity. Businessmen who believe that everything they earn will be stolen, expropriated or taxed heavily have no incentive to work, never mind investment and innovation activities. However, it is important to protect property rights of both sides - the economic elite and general public.

Thus, one can argue that the statement about the fatality of the property tax of $2 \%$ in Irkutsk regional law has been taken into account. On the other hand, fears that the tax will be imposed on all property items fallen within the purview of the law irrespective of the property floor area have panned out earlier than expected. Since January 1, 2018, all property items having cadastral numbers will fall within the purview of the law irrespective of their floor area. A year earlier, only property items with a floor area of more than $1000 \mathrm{~m}^{2}$ were taxable.

During this short period until the beginning of 2018, it is necessary to determine the tax rate which, on the one hand, would contribute to regional and municipal budget replenishment and, on the other hand, would not do much harm to SMEs.

In [1], it was proved that the tax rate of $0.1 \%$ would force 5 percent of SMEs to go out of business. Those SMEs might go out of business without adopting the law because of their sad state. The tax rate of $0.4 \%$ would force 60 percent of SMEs to go out of business. The tax rate of $1.3 \%$ would force all SMEs to go out of business.

Hence the question arises whether these calculations are relevant for the regional economy of the end of 2017. Is it possible to determine the tax rate which would solve a double task in 2018 - ensuring budget replenishment and preventing businesses from being shut down? The present article attempts to answer these questions.

During public debates, representatives of Irkutsk Government put forward arguments for the maximum tax rate of $2 \%$ arguing that it is not fatal for SMEs while their reluctance to pay larger tax bills is only due to their greed. That approach (businesses should be hard controlled and their complaints should be disregarded) is typical for Irkutsk region and Russia as a whole. 
The well-known extract taken from the work by a British publisher and a labor leader Thomas Josef Dunning and cited by Carl Marx in his "Capital: Critique of political economy" (Volume I. Chapter XXIV "The primary accumulation of capital", Part 7 "The accumulation of capital"), is deeply embedded into the thinking of some public officials: Capital is said by Quarterly Reviewer to fly turbulence and strife, and to be timid, which is very true; but this is very incompletely stating the question. Capital eschews no profit, or very small profit, just as Nature was formerly said to abhor a vacuum. With adequate profit, capital is very bold. A certain 10 per cent will ensure its employment anywhere; 20 per cent will certainly produce eagerness; 50 per cent - positive audacity; 100 per cent will make it ready to trample on all human laws; 300 per cent and there is neither a crime at which it will scruple, nor a risk it will not run, even in case its owner being hanged. If turbulence and strife will bring a profit, it will freely encourage both. Smuggling and the slave-trade have amply proved all that is here stated (T.J. Dunning, cit., pp. 35, 36)".

In the Czarist-era, only a trading license is authorized to carry out commercial activities. The Acts on Trading Taxes (1863-1865) and on State Business Tax (1898) prescribed the procedure of issuing trading documents. The entrepreneurs themselves determined a guild and a category of their shops and had a trading license of a certain guild. It is similar to the uniform tax on imputed income (UTII) calculated and paid by businessmen depending on taxation objects.

Did all entrepreneurs of the Czarist era pay their taxes in a fair way? Unfortunately, they did not. According to the audit findings, in 1882 more than a quarter of commercial and industrial institutions of Yenisei and Kansk districts carried out uncontrolled activities [10].

The description uncontrolled can mean not only illegal. As an example, one can use the case of N.G. Gadalov, a Kansk entrepreneur. In 1888, he dealt with textiles, grocery and wholesaling. For wholesaling, he used a stone building consisting of two rooms with two towers. In front of the building, there was a sheltered space where he kept barrels with sugar. The sheltered space provoked a conflict between the businessman and local authorities. According to the local authorities, Gadalov underpaid taxes amounting to 787 rubles - at that time it was a vast amount of money - due to incorrect gradation of the business.

The businessman paid the tax but appealed against the decision of the local authorities to the Ministry of Finance of Russia. The Ministry admitted that the shadow created by the sheltered space is not real property and returned him 761 rubles as illegally collected. However, 26 rubles were kept as a fine [11].

This historical retrospective illustrates constant conflicts between Russian businessmen and public authorities which are not always safe both for entrepreneurs and public officials.

\section{METHODOLOGY}

In 2012-2016, more than 200 laws on financial relations between the Government and business amending the Criminal and Administrative Offences Codes were adopted [3]. For four and a half years, the volume of the Criminal Code increased by $28 \%$, the volume of the Administrative Offences Code - by $44 \%$, the volume of the Criminal Procedure Code - by 9\%. All these amendments are of incriminating nature. Humans are referred to as violators, offenders and thieves.

People are afraid of starting business because there is a number of methods to initiate a criminal case against them. Russia ranks third by the number of prisoners, tenth - by the number of prisoners per 100000 of the national population, and second - among the largest countries. However it ranks $50^{\text {th }}$ place by the human development index (education, medicine, welfare) [3] and $129^{\text {th }}$ place by the life expectancy index followed by African nations [4]. In 2016, 200000 criminal cases on economic crimes were being pended [14].

However, at the federal legislative level, one can observe some attempts to modify that oppressive situation. Public officials began to understand that economic development of Russia and growth in Russia's citizens' prosperity depend on the level of business development. The Federal Act no 436-FZ of December 19, 2016 amended Article 299 of the Criminal Code and Article 151 of the Criminal Procedure Code. The amendments are provided for severe punishment for falsification of criminal cases against businessmen.

The Act aims at strengthening punishment for illegal criminal prosecution. It increased the maximum prison term for that crime from five to seven years of imprisonment. The same crime, associated with the accusation of a person of committing a grave crime or an especially grave crime, is punishable by ten years of imprisonment. The same punishment is provided for illegal criminal prosecution aimed at stopping business activities from mercenary or other personal motives.

According to the amendments in the Criminal Procedure Code, investigation into the cases on the crimes stipulated in Article 169 of the Criminal Code "Preventing from legal business activities" was carried out by the Investigation Committee of the Russian Federation.

Economic conflicts should be solved by using criminal procedures and illegal criminal prosecution against businessmen.

Government security officers are also used by businessmen who wants to deprive their colleagues of lucrative business employing criminal methods.

In November 2016, the Plenum of the Supreme Court adopted Regulation No 48 "On criminal cases on business and other economic activities". It was emphasized that it is important to protect rights and property of those businessmen who are faithful in running business. Those ones who commit crimes to eliminate competitors have to be prosecuted.

Criminal laws are getting more liberal. Recently, it has been adopted a new legislative act which makes it possible to substitute imprisonment for fines, but some regionals officials continue to consider entrepreneurs as heroes of the work by T.J. Dunning. 
According to their viewpoints, entrepreneurs are greedy by nature and do not wish to share their profits. The regional government can maximize the property tax rate but what effects that increase will cause. Irrational increase in the tax rate can cause a situation similar to the one in Greece when seven years of the economic recession caused property prices collapse. Compared with 2009, real estate in Greece fell by $45 \%$ and is still getting cheaper. Due to increasing tax rates, many owners attempt to dispose of their property, renounce succession as heirs and even donate their houses and apartments to the state. Greek real estate agents argue that high tax rates harm the investment attractiveness of the local real estate sector which was a key pillar of the national economy. As a result, in Greece, the supply exceeds the demand: the number of real estate transactions reduced by $87 \%$, and the data base contains more than 250000 real estate units. In Athens, Salonika and other large Greek cities, dozens of thousands of apartments are abandoned. The per square meter price fell to 300-400 euros, whereas in 2008, it amounted to 1000 euros. Being unable to sell their apartments, the Greeks rent them at fire-sale prices. Numerous ads for sale or to rent speak for the sorry state of the local real estate market $[12,13]$. It should be noted that that property is located in the Mediterranean, not in cold Siberia.

Crudity and undue haste of the regional authorities increasing property tax rates are typical for the history of Irkutsk oblast. For example, in Bratsk there is a plot of land where a pulp and paper plant owned by Group Ilim is located. The conflict resulted from the implementation of the cadastral value approach when calculating property taxes. The government of Irkutsk oblast increased the cadastral value several times. The cadastral value for the plot of land owned by Group Ilim in Bratsk was above seven billion rubles.

The owner filed a dispute resolution request to equal the cadastral value of the plot of land with the market one (the law entitles to it). The tax amount decreased 15-fold (452 million rubles). Having challenged the decision in court, the municipal government won a suit. However the courts of appeals, including the Supreme Court, reversed that decision.

As a result, the local budget did not manage to gain additional income. Worse still, revenue from the property tax sharply decreased by tens of millions of rubles.

The regional government displayed such qualities as incompetence, inability to calculate the risks of decisions made, unwillingness to apply scientifically grounded ideas about social and economic aspects.

What is the current social and economic situation? In the first part of the present article, authors presented sad statistical data on different aspects of the Russian economy as of December 2015. What changes happened since that time?

One in three employers is going to reduce employees and salaries. In the first half of 2016 , the salary in retail business (where most SMEs workers are employed) was 16078 rubles, in the clothing manufacture (which is also negatively influenced by the new law), the salary was 9939 rubles, a minimum living wage.
The population of Irkutsk oblast is 21400 million people. (14.6 percent of the total number of the Russian citizens). In the first half of 2016, the monthly income was less than 10000 rubles. To be specific, in the second half of 2016, in Russia, the value of the minimum living wage per capita was 9956 rubles per month, in the first quarter - 9776 rubles.

The crisis increased the number of people living below the national poverty line. In the first quarter of 2016, the number of such citizens increased to 22.7 million people. For comparison, in the fourth quarter of 2015, 14.4 million Russian citizens lived below the poverty line.

More than 1.5 million Russian people work abroad due to low level of salaries in Russia.

Today, 20 percent of the poorest Russian people get only 25 percent of financial resources allocated for the social assistance. In the countries with a social support principle implemented, that index exceeds 50 percent.

According to the data of the Russian Statistics Committee, in 2016 , food prices increased by $4.6 \%$, non-food prices - by $6.5 \%$, service prices - by $4.9 \%$. In the EU, food prices increased only by $0.5 \%$ [14].

Compared to the two previous crisis years, in 2016, price increase was not so significant. In 2015, for example, annual inflation was set at $12.9 \%$, and in 2014 - at $11.4 \%$. But if one takes into account that real income of the population has been decreasing for already two years, that price increase has negative effects on welfare of the Russian people. According to the data of the Russian Statistics Committee, in 2016, real incomes (average inflation-adjusted after-tax incomes) of the Russian people decreased by $5.8 \%$ compared to the same period of the last year.

It should be taken into account that in 2015 and 2016 , incomes of the Russian people decreased as well. The Institute for Social Analysis and Prediction RANEPA calculated that real incomes of the population decreased by $12.3 \%$ for two years, real salaries - by $8.7 \%$, and real pension rates - by $7 \%$.

According to the prediction of the Ministry of Economic Development, by the end of 2017, the number of poor people in Russia will have increased to $13.7 \%$ (from $13.1 \%$ in 2015). The peak poverty rate of $13.9 \%$ is expected to be in 2018 .

In the coming three years, due to the abolition of the indexation of pensions for working pensioners (at present, in Russia there are 30 million non-working and 10 million working pensioners), pension rates will decline by $0.5 \%$, despite the fact that in 2017 , the Russian authorities decided to adjust pensions according to the annual inflation rate.

In the first half of 2016, the volume of commercial services declined by $0.9 \%$, retail business - by $5.7 \%$, housing development - by $9.2 \%$ compared to the same period of 2016 .

Real budget revenue has been constantly declining for three years. The Ministry of Finance is going to reduce it by 15-20\% within the next three years. Besides, a large budgetary gap exceeding $35 \%$ of the GDP, huge debts of the Russian regions, serious bank crisis accompanied with annual bankruptcy of more than 100 banks, zero loan growth and 
significant reduction of investment loans, acute currency crisis, ruble devaluation, foreign currency inflow reduction, capital drain are inherent features of the current Russia's economy.

GDP volume, investment, building, machine and equipment production, retailing and commercial services are indices of incomes and consumption of the population which continue to decline deepening the country's economic crisis. If in the first half of 2016 the GDP rate decreased three-four-fold compared to the same period of 2015 , the investment rate, building and retailing indices, real incomes, consumption index, education, health and social insurance funding, including pension rates, declined by 5 percent [15].

Salary debts are also increasing: as of January 2016, they were 3.5 billion rubles, and as of December 2016 - 3.85 billion rubles. In 2016, the number of criminal cases on salary debts increased significantly (494 criminal cases against 505 accused).

According to the approach of the International Labor Organization, as of November 1, 2016, there were 4.1 million unemployed per 76.7 million economically active people (52\% of the Russian population). It is five times as much as the number of the registered unemployed -848 thousand people [16].

For the first time since 2004, the number of liquidated companies exceeded the number of created ones. According to the data of the Russian Statistics Committee, from January to November 2016, 571282 companies were dissolved, 381144 companies were created. Thus, the total number of companies hit a low: at the beginning of 2017, there were 4.5 million registered enterprises. As a comparison, in 2004, there were 4.4 million companies.

Thus, one can argue that the state of the Russia's and Irkutsk oblast's economies did not undergo positive changes, and the recession continues.

If this is true, from a crisis management perspective, the increase in the property tax rate is incorrect.

\section{RESULTS}

In 2017, tax load growth will contribute to a further decrease in business activities and shadow economy growth. As far as commercial enterprises go underground more often than manufacturing ones, their numbers will significantly decline giving way to low-quality grey imports.

Amid the global production crisis, products quality deterioration and increase in counterfeit products are unavoidable due to weak control of regulatory authorities and high level of regulatory corruption rather than forced cost saving.

It should be noted that the government of Irkutsk oblast can grant tax remission to any enterprise. For example, at the end of 2015, the government granted property tax exemption to Heineken Baikal Brewery.

The tax amount was 10 million rubles which will not be transferred to the regional budget. What's interesting,
Heineken is not a poor company. Its profit before tax is 900 million rubles.

Several years earlier, property tax exemption was granted to a Moscow Brewery Company SanInBev. Tax exemption did not work for the region's economy as in 2014, the company closed down its branch in Angarsk.

It appears that the taxation policy of Irkutsk oblast aims at supporting the alcoholic beverage industry. Availability of alcoholic products is not an issue for the population of Irkutsk oblast. According to the data of the Irkutsk Statistics Committee, in 2015, 5657 shops sold alcoholic products (in 2012 - 4 904), i.e. one shop per 330 residents.

The total floor area of shops in Irkutsk oblast is 972883 $\mathrm{m} 2$, of which $216743 \mathrm{~m}^{2}$ - of food stores, and $756140 \mathrm{~m}^{2}-$ of non-food stores. Shopping space availability is $1623 \mathrm{~m}^{2}$ per 1000 residents (at the rate of $665 \mathrm{~m}^{2}$ ). In Irkutsk, there are four retail markets, two hypermarkets, one small wholesale market, 93 supermarkets, 1771 shops, and 1563 nonstationary shopping facilities (pavilions) of 4421 shopping facilities of Irkutsk oblast.

Imposition of the obligation to maintain the property on SMEs not to speak of the property tax imposition is intolerable burden and makes enterprises search for new non-core activities using the same facilities. Seven of ten SMEs engage in non-core commercial activities in order to prevent decline in demand and profit and avoid bankruptcy.

The number of services provided by business centers is increasing. Apart from renting out commercial facilities, business centers rent out parking spaces, conference spaces, and provide clearing and logistics services.

In the food service industry, 43 percent of cafes and restaurants conclude contracts for office catering, provide lunch delivery services to tourist groups and building companies.

It ensures stable demand for catering services. Non-core activities can bring 20 percent of the company's income. Cafes and restaurants function as café-restaurants in the daytime and as café-bars at night. Customers are attracted by broadcasting of sports events.

According to the data of the Irkutsk Statistics Committee, the number of optimistic entrepreneurs sharply declined. In 2014, 22 percent of entrepreneurs described the economic situation in the region as favorable. In 2015, that number reduced to $14 \%$, and in 2016 - to $4,5 \%$.

The data show the direct dependence of the business climate on deterioration of external economic factors and the effective date of the law under study. The closer the effective date is, the less optimistic the entrepreneurs are.

When calculating property tax rates, entrepreneurs used real market prices as the cadastral value of the property were undercut by $10-20 \%$. According to the calculations of the Ministries of Property Relations and Economic Development of Irkutsk oblast, the mean cadastral value of one square meter in taxable shopping facilities was considerably lower - from 14-16 thousand rubles (shopping centers Ruchei, Europark, 
etc.) to 23 thousand rubles per square meter (shopping centers Senator, Modny kvartal, etc.) in Irkutsk, 5.3-18 thousand rubles per square meter in Angarsk (the mean value is 12-14 thousand rubles), 14-17 thousand rubles per square meter in Sludyanka, and 11-12 thousand rubles per square meter in Chuna.

For this very reason, tax rates calculated by premises owners and regional authorities differ significantly.

Calculations made by the premises owners and author of the present article are closer to the meaning of the legal concept of cadastral value.

As a part of the research, the author conducted an opinion poll among heads of the SMEs in Irkutsk, Angarsk, Shelekhov, Usolye-Sibirskoe and Bodaybo to determine the maximum possible value of the property tax calculated by the cadastral value which would allow SMEs to survive under current economic conditions. It should be emphasized that the heads of the SMEs gave economically grounded statements rather than answers off the cuff. The poll results are shown in Figure 1.

Figure 1 shows that if the tax rate is $0.1 \%, 5$ percent of SMEs owning reals estate with a floor area of less than 1000 $\mathrm{m} 2$ will go out of business. It is possible that those SMEs will go out of business irrespective of the tax rate due to their sad financial situation. It illustrates that the sector of small business stands on the brink of the financial black hole. If the tax rate is $0.4 \%, 60$ percent of the SMEs will cease to exist. If the tax rate is $1.3 \%$, all the SMEs owning real estate taxable subject to the property tax stipulated in the Act on the property tax will cease existence.

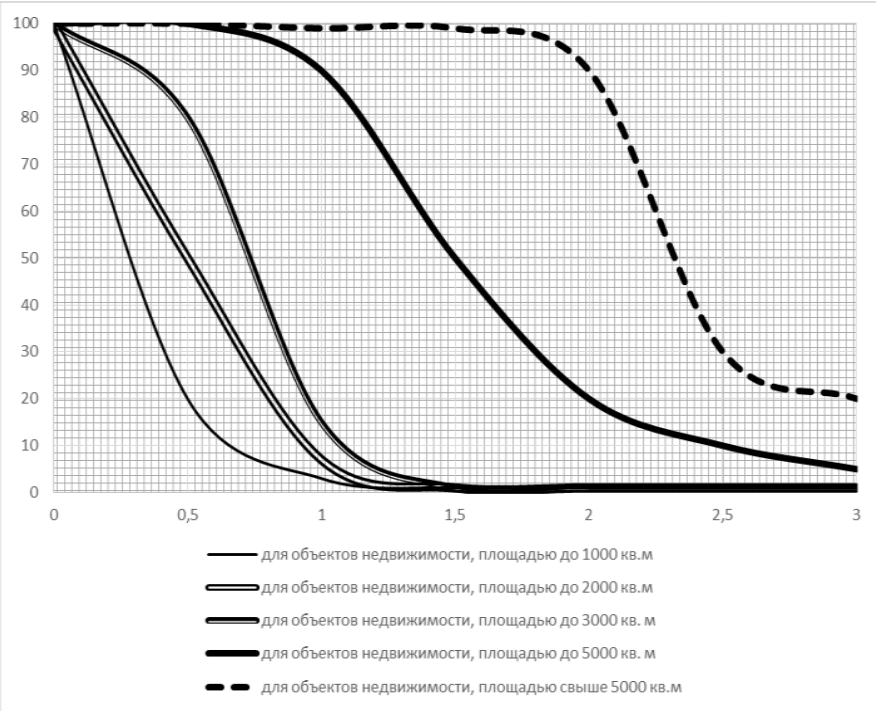

Fig. 1. Dependence of the number of enterprises forced to shut down their business activities on the property tax rate

\section{Axis of abscissa - the tax rate from 0 to $3.0 \%$.}

Axis of ordinates - the number of SMEs in Irkutsk oblast; the number of SMEs as on January 1, 2017 is taken as $100 \%$.
Figure 1 shows that increase in the floor area boosts the probability of shut down for SMEs. For example, if the floor area of an office or a shopping center is more than $5000 \mathrm{~m}^{2}$, tax effects are neutralized.

For research purposes, the author assumed a tax rate exceeding the legaly provided maximum rate of $2 \%$ in order to determine if there are chances of survival for large businesses.

Figure 1 shows that the tax rate exceeding $2 \%$ is critical even for large business.

\section{DISCUSSION}

If the property tax rate is $2 \%$ of the cadastral value (initial position of the government of Irkutsk oblast initiating a bill on the property tax), the share of that tax from the profit after tax under the simplified taxation system (STS) is 48.2-95.5\%. It is highly unlikely that an entrepreneur will run business under these circumstances unless he is not able to unlock his business capacities in some other areas or regions. Combining the results for commercial facilities with a floor area of above $1000 \mathrm{~m}^{2}$ with earlier calculations for smaller facilities, one can identify a trend: for the facilities with a floor area of less than $1000 \mathrm{~m}^{2}$, the tax rate of $2 \%$ is more fatal. The tax amount exceeds 100 percent of profit. The situation is due to stiff competition in that market segment which is beneficial for the consumer as it decreases prices. In fact, the prices do not decrease due to weak profitability of businesses caused by decreasing purchasing ability and increasing expenses on real estate management. Increase in expenses results from rise in the prices of electricity, housing services, petrol, railroad rates. The prices continue to rise despite the economic crisis, against common sense and scientific recommendations.

\section{CONCLUSION}

The calculations show that whatever be the increase in the tax rate in Irkutsk oblast, things for the SMEs owning real estate with a floor area of less than $1000 \mathrm{~m}^{2}$ (more than $90 \%$ of SMEs) will get worse. Nevertheless, the law has been adopted.

The way out is to introduce a tax rate of less than $0.2 \%$.

The owners of large shops and offices, which pay taxes under the STS, will enjoy significant fiscal loosening, but it will correspond to scientifically ground anti-crisis management.

The tax rate of $0.2 \%$ will not be shock for all SMEs. Increase in the tax rate will force 15 percent of SMEs (real estate owners and real estate tenants) to go out of business and others - to adapt for additional burden.

In general, adoption of the Act on the property tax will not improve the business climate for small and medium businesses. In 2019, it will decrease the number of SMEs, increase the number of the unemployed and cause shadow economy growth. 


\section{Acknowledgment}

The authors acknowledge receiving support from the statefunded research program of Irkutsk National Research Technical University. We are responsible for all errors as well as heavy style of the manuscript.

\section{References}

[1] I.I. Galyautdinov, Possible economic and social consequences of the changes in the law of Irkutsk region "On the bsuiness property tax" for small and medium businesses of the region. Vestnik Irkutskogo gosudarstvennogo tekhnicheskogo universiteta [Proceedings of Irkutsk State Technical University], no. 10 (105), pp. 217-224, 2015.

[2] D. Adzhemoglu, D. Robinson, Pochemu odni strany bogatye, a drugie bednye. Proiskhozhdenie vlasti, protsvetaniya i nishchety [Why are some countries rich and others poor. The origin of power, prosperity and poverty], Moscow, AST Publ., 2015.

[3] D. Acemoglu, Politics and Economics in Weak and Strong States. Journal of Monetary Economics, vol. 1, pp. 199-226, 2005.

[4] D. Acemoglu, "Reevaluating the Modernization Hypothesis," Journal of Monetary Economics, vol. 10, pp. 43-58, 2009

[5] Th. Piketty, E. Saez, "Income Inequality in the United States, 19131998," Quarterly Journal ofEconomics, vol. 1, pp. 29-30, 2003.

[6] W. Kopczuk, E. Saez, J. Song, "Inequality and Mobility in the United States: Evidence from Social Security Data since 1937," Quarterly Journal of Economics, vol. 1, pp. 91-128, 2010.

[7] T. Yakovleva, Bez bumazhki ty bukashka [It is the piece of paper that makes the difference]!Rodina, 2016, July (no. 7), p. 100.
[8] N. Kozlova, Posadka po zakazu [Landing at request]. Rossiiskaya gazeta, 2017, January (no. 6), p. 1.1

[9] Th. Piketty, Capital in the Twenty-First Century. London, The Belknap Press of Harvard University.

[10] N. Wolff Edward and Ajit Zacharias, "Household Wealth and the Measurement of Economic," vol. 2, pp. 83-115, 2009.

[11] S.N. Kaplan, J. Rauh, "Wall Street and Main Street: What Contributes to the Rise of the Highest Incomes?" Review of Financial Studies, vol. 3, pp. 1004-1050, 2009.

[12] Ch.H. Smith, When Assets (Such as Real Estate) Become Liabilities. Available at: www.washingtonsblog.com/2016/12/assets-real-estatebecome-liabilities.html (accessed 27.12.2016).

[13] F. Pawel, Taxes on real estates in The Europen Union Countries - the oretical and practical considerations. Available at: http://yandex.ru/clck/jsredir?from=yandex.ru\%3Bsearch\%2F\%3Bweb\% 3B\%3B\&text=\&etext=1321.ejZp6Rf5_eqB (accessed 21.10.2016).

[14] V. Gudkova, Polugodovoi ekonomicheskii otchet: krizis eshche tut ili uzhe ushel [Semiannual economic report: is the crisis still here or has already gone]? AIF, 2016, July (no. 30), p. 20.

[15] A. Aganbegyan, Tochnyi diagnoz [Precise diagnosis]. AIF, 2016, September (no. 39), p. 18.

[16] T. Bogdanova, Zhdat' li pribavki? [Should we wait for the raise?]. AIF, 2017, no. 1-2, p. 10.

[17] E. Maksimova, Glavnye syurprizy novogo naloga na nedvizhimost' [Main surprises of a new residential tax]. Komsomol'skaya pravda, 2016, October (no. 122), p. 12. 